\title{
Medical confidentiality and multidisciplinary work: child sexual abuse and mental handicap registers
}

\author{
ROGER WILLIAMS, T HARI SINGH， JEANNETTE NAISH， ARNON BENTOVIM, \\ D P ADDY, RAANAN GILLON, CLARE DYER
}

\begin{abstract}
We received a short paper from $D r$ Williams raising the issue of medical confidentiality as encountered by general practitioners in cases of child sexual abuse. Similarly, we received a letter from $D r$ Singh describing a conflict with his local social services department about the confidentiality of information requested by the department for inclusion in a mental handicap register. We asked a general practitioner, a consultant psychiatrist, a consultant paediatrician, an expert in medical ethics, and a solicitor to comment on these two cases.
\end{abstract}

Department of Child and Adolescent Psychiatry, Beck House, Scarborough
YO12 5ED ROGER WILLIAMS, MRCP, MRCPSYCH, consultant psychiatrist

Hensol Hospital, Pontyclun, Mid-Glamorgan, and Llwyneryr Mental Handicap Unit, Swansea SA6 6AH

T HARI SINGH, MRCPSYCH, DPM, consultant psychiatrist

London N9 8RZ

JEANNETTE NAISH, MB, MRCGP, general practitioner

Department of Psychological Medicine, Hospitals for Sick Children, Great Ormond Street, London WCIN 3JH

ARNON BENTOVIM, FRCPSYCH, DPM, consultant psychiatrist

Dudley Road Hospital, Birmingham B18 7QH

D P ADDY, FRCP, DCH, consultant paediatrician

Imperial College of Science and Technology, London SW7 1NA

RAANAN GILLON, MB, MRCP, director, health service

London NW1 7EG

CLARE DYER, BA, BLS, legal correspondent

\section{The case of child sexual abuse}

At a recent meeting of a wide variety of different professionals dealing with child sexual abuse allusions were made to how difficult it is to include general practitioners within the system of information sharing that other disciplines consider essential for the satisfactory management of cases of child sexual abuse. As a child psychiatrist, I think that I perhaps have a better understanding of the general practitioner's predicament than most other professionals. I have debated this issue with other members of the team at Paxton House (a child psychiatry unit offering specific treatment services to children who have been abused and families in which abuse has occurred), where I used to work, and we wish to promote further discussion of this issue by asking for views, from people both within and outside the medical profession, on the following case history.

A mother attends her general practitioner by appointment with her 13 year old daughter. She emphasises that the problem for which they are consulting is strictly confidential; the general practitioner confirms that it will be treated confidentially. Mother and daughter then describe the sexual relationship that has taken place over 18 months between the child and her stepfather. She has apparently only just been able to confide in her mother. The sexual contact has increased from initial inappropriate genital touching by her stepfather to full sexual intercourse. On occasions he has threatened violence, and when the general practitioner suggests that the mother and daughter should contact the police both are visibly scared and admit to being frightened of the physical consequences of doing so. The stepfather is also a patient of the general practitioner having consulted occasionally with dyspeptic symptoms. He is in regular employment and an active member of the local Rotary group. A partner has added to his notes "? drinks too much." 
The general practitioner agrees to see mother and daughter together and sets aside an hour to do so. She physically examines the child, establishes that there is no major genital injury, and carries out a pregnancy test, which gives a negative result. She counsels mother and daughter and agrees to see the daughter alone every month. Some 10 weeks later she is consulted by the daughter, who is in a distressed state and explains, "It's all happened again." Again she finds no evidence of physical injury or pregnancy, and a pregnancy test gives a negative result. The general practitioner consults by telephone with the child's mother and once again requests that further help should be sought; the mother will not permit this. The monthly meetings continue for 18 months, at the end of which time the girl says that she has not received any inappropriate attention for a year. She is now 15 years old and has just started her $O$ level year; mother and daughter and general practitioner agree that the regular sessions may stop.

Five months later the senior partner of the practice is called out at $2 \mathrm{am}$. The girl is dead, having been strangled and sexually assaulted by her stepfather. The stepfather has been arrested by the police and is subsequently charged with murder. The mother is initially hysterical, but once calm she is able to tell her own father of the lengths to which she had gone to stop her husband becoming angry and killing her daughter "just as he did last night." The maternal grandfather is a senior social worker in the local social services department. He is incensed that the general practitioner did not follow the accepted code of practice established within the county in consultation with the family practitioner committee-that is, that any general practitioner who suspects child abuse should seek a paediatrician's opinion and call in a representative of the divisional social services department. ${ }^{1}$ He seeks legal advice to sue the general practitioner.

Is the general practitioner culpable in the eyes of the criminal court, the civil court, the General Medical Council, her colleagues, or society?

1 Berkshire Social Services Department. Procedures in response to child abuse. Reading: Berkshire County Council, 1986.

\section{Dr Jeannette Naish comments:}

In cases of child sexual abuse general practitioners are often caught between their responsibility for the child's safety and their responsibility to the family as a whole. Preservation of the relationship between individual members of the family and the general practitioner is also a dilemma and sometimes clouds the issues.

It would have been impossible to anticipate the terrible outcome in the case proposed by Dr Williams. As the mother imposed constraint on the general practitioner not to disclose information given during the consultation the general practitioner was drawn into the mother's collusion with the stepfather in sexually abusing the child. I think that it was inappropriate to counsel the child. A child has no power to alter something imposed by a powerful adult such as her stepfather. Counselling would have little effect other than to allow the doctor to keep an eye on the child. It would have been impossible to confront the stepfather with confidential information received from the mother.

The threat of violence and the evident fear of the mother and child caused concern for the child's safety; the general practitioner's duty here was to protect the child. The mother was clearly concerned for the marital relationship and its preservation. I would have taken the decision out of her hands and sought the advice of a trusted paediatrician. It is easier for an impartial third party to prescribe the correct course of action.

General practitioners are the most accessible medical agency and therefore in the front line when it comes to child sexual abuse. Many of us are unclear in our attitudes about responsibilities and taboos and have no specific training on this subject. I would welcome clear guidelines on suspected child sexual abuse, and I think it unwise not to follow an already established code of practice: this was a case of actual child sexual abuse.

\section{Dr Arnon Bentovim comments:}

The problem of a family member asking that information be kept confidential before imparting it is a common one for all professionals. The problem for general practitioners who have all members of the family on their list is to balance the needs for confidentiality of all their patients and to decide whether the protection of a child should take primacy over the issues of confidentiality of the adults or is equal to them. The courts concerned with child care issues see the child's interests as paramount. I believe that any professional with a child as a client should take a similar view.

A view has been put forward that adults with major problems, such as those who abuse children, may be living out problems from their formative past and therefore deserve our sympathy and support. This is of course true, but children live in a formative present that may have lasting consequences for their future survival and their lives as adults, and we need to consider this if we believe a child is being abused. When general practitioners ask if I will see a patient to help them deal with child care I advise that links be made with social services departments because the guidelines I have accepted for practice suggest that children whom I believe to be abused or at serious risk of future abuse should be reported. If a general practitioner were to say that he wished to keep confidential the matters he had learnt, and not have them reported, I would suggest that with medical confidentiality he could choose to work with the family as the general practitioner did here, although guidelines apply to all of us. But I would point out that he was now the protective professional in the case and that if matters were to go wrong he would be responsible; thus his judgment might very well be questioned.

I prefer to share such issues with social services departments because I do not have the resources to supervise child care properly and can offer therapeutic work, which may help change the situation; I cannot offer protection meanwhile. Although the general practitioner here offered support to the girl and to her mother, there was evidence of recurring abuse after some 10 weeks' supervision. The difficulty was that the general practitioner was stopped by the mother from seeking further help. At this point the general practitioner might have said that her supervision of the girl and the mother was not successful and she could not guarantee the girl's safety because of past violence, fears of future violence, and a risk of future sexual abuse in an unprotected situation. There is adequate guidance to support her in no longer maintaining confidentiality despite the mother's request.

The General Medical Council indicated quite clearly that "disclosure [of confidential information] may be justified on the ground that it is in the public interest which, in certain circumstances, such as, for example, investigation by the police of a grave or very serious crime, might override the doctor's duty to maintain his patient's confidence." The Department of Health and Social Security's guidelines on confidentiality state: "the safety of the child must in all circumstances be of paramount importance and must override all considerations. The sharing of information is, therefore, on a 'need to know' and for those directly concerned with the family and who have the duty legitimately to perform a service on its behalf and taking action in the light of all the relevant facts."'

A man who has not only abused a child but has done so repeatedly is at serious risk of continuing to do so if the matter is not brought into the open. The threat and fear of violence often prevent people speaking. For a general practitioner to take on the responsibility of such a case without assessing the abuser or sharing with other colleagues, and being an agent of child care without adequate resources, is clearly a risky enterprise.

Perhaps if we are asked to keep confidentiality before knowing what the confidential information is we should make it clear that we cannot commit ourselves in advance to agreeing to such a course, which might go against the interests of a child in the family. Perhaps if the mother knew that confidentiality regarding the possible abuse of a child could not be kept she would have to confront the fact that abuse and threats of violence cannot be kept a secret in the hope that they will go away. She might then think through with her general practitioner how to approach statutory authorities so that the 
welfare of her child could be assured and proper safety provided, and the possibility of help for herself, her daughter, and her husband explored instead of this tragedy occurring.

1 General Medical Council. Professional conduct and discipline: fitness to practise. London: GMC 1987:20.

2 Department of Health and Social Security. Guidelines on confidentiality. London: DHSS, 1976

\section{Dr D P Addy comments:}

Murder is not a common end result of child sexual abuse, and to that extent the case history is atypical and misleading. Any doctor's overriding responsibility is the welfare of his or her patient. In this case the patient is the child. The mother cannot insist on maintaining confidentiality to the child's detriment and the initial promise of strict confidentiality must be taken on that premise. The abuse continued after the general practitioner was consulted and she knew that it was continuing. The general practitioner was therefore failing in her duty to help and protect the child. I cannot imagine what benefit she might feel would result from monthly meetings with the child. Counselling, knowing that the abuse is continuing, seems to me to be a form of professional self deception. I would like to think that the doctor could have discussed the problem with her local paediatrician, and in my opinion the matter should have been referred to the social services department. Informing the police would preferably depend on interprofessional discussion, probably in the form of a case conference, although many senior social workers might consider that with this history they should inform the police from the outset, and I could not dissent from that opinion.

The management of child abuse of all kinds is increasingly becoming a specialised subject within paediatrics and child psychiatry and few general practitioners can be expected to have the necessary skill. Unless the general practitioner has a special interest in and experience of the subject he or she would be well advised to seek expert help at an early stage.

\section{Dr Raanan Gillon comments:}

This is a particularly difficult and horrible case and could receive only a thumbnail sketch of an analysis even in three times the allotted space. Horrible though the outcome was, I would not allow it to influence my assessment of how the general practitioner should properly have acted for the probability of murder in such a case is simply too low for it to be taken into account prospectively. Horrible possible consequences of any action have to be discounted in relation to their probability.

At first consultation, however, the probability of further harmful and criminal sexual assaults by the stepfather on the girl was high. Several moral concerns are relevant. Firstly, doctors implicitly promise to keep patients' secrets and this doctor explicitly did so. Keeping such confidences can be justified both in terms of respect for people's autonomy and in consequentialist terms of sustaining a general trust in the medical profession such as is conducive to optimal medical care and thus the general good. ' Secondly, doctors have an obligation to do their best for their patients' health and to do so with minimal harm (beneficence and non-maleficence). Finally, doctors have to act within a framework of justice. In this case distributive justice is irrelevant but justice in terms of protecting people's rights is relevant, notably children's rights not to be criminally sexually abused, especially not by their parents because parents (including of course step-parents) have both enormous power over their children and a great responsibility to care for them.

Two possible arguments in favour of maintaining confidentiality are $(a)$ that medical confidentiality is an absolute obligation, like that of the confessional, and cannot be broken whatever the consequences; and $(b)$ that it is at least a very strong medicomoral obligation and can be overridden only where extreme harms result. Severe harms to the child result in this case whatever course of action is followed, and the net saving of harm to the child by breaking confidentiality may not be sufficient to justify breaking this important moral obligation.

The main opposing arguments are that maintaining confidentiality in this case does not respect the child's autonomy, does not serve the common good, and is against the child's interests. The autonomy of the child is not respected because the child does not want the sexual abuse to continue and agrees with her mother (assuming she does) that confidentiality must be maintained only because she is effectively coerced into doing so by her fear of her stepfather. Furthermore, it is doubtful if a child of 13 has sufficient autonomy to require that confidentiality is respected when to do so will be seriously harmful to her. The socially acceptable system whereby parents normally make proxy decisions on behalf of their children assumes that they will act in their children's interests. Such an assumption is gravely undermined if a parent is unwilling to take steps to stop further sexual abuse of her child. So far as the common good is concerned, colluding with sexual abuse of children is against the common good. And the child's best interests require that any further sexual abuse, which is likely to be damaging to her psychosexual development and future flourishing, be stopped.

Received wisdom currently favours the second line of argument. A Ciba Foundation working party on child sexual abuse within the family advises all professionals faced with such problems to avoid dealing with them alone. ${ }^{2}$ Multidisciplinary teamwork is needed, including social workers, paediatricians, psychiatrists, and the police, with protection of the child and rehabilitation of the offender being the objectives. If necessary confidentiality should be overridden to achieve these objectives. ${ }^{2}$ Both the General Medical Council's and British Medical Association's guidelines on confidentiality specify exceptions to the obligation to maintain confidentiality that could justify overriding it in this sort of case. ${ }^{34}$

I find both lines of argument highly persuasive (a real dilemma) and after much reflection am inclined to try for a middle way. Thus if faced with such circumstances I think I would make clear to the mother and her daughter that current advice to doctors is that they should report cases of child abuse, including sexual abuse, to the local social services, who are obliged to report them to the police. To try to respect their autonomy as well as to minimise harm to the child, however, I would propose a course of action to which they might agree. I would write a letter to the stepfather and ask them to give it to him; in the letter I would explain that I had been told about the sexual abuse and that according to the norms of good practice I should report it. I would say that I was keen, however, to minimise the trauma to his stepdaughter, my patient, and to him and his wife, also my patients, and I would therefore invite him to confirm as a matter of urgency that $(a)$ he would come to see me to seek ways of overcoming his problem and $(b)$ that he would promise to stop abusing the child. I would also wish to see the daughter on a regular basis. If I failed to receive his agreement or if there were any further episodes of abuse I would acknowledge my powerlessness to help and refer the matter to the social services and thus the police.

I think that this course would offer mother and daughter a way of agreeing to action that might achieve the desired objective of making further abuse reasonably unlikely (as the stepfather would know that if it occurred again he would be reported to the police) while also protecting the daughter from the considerable immediate harm that reporting to the police would probably produce; this would include separation of the family, appearance in court and publicity with subsequent damage to all including the girl, and punishment, probably imprisonment, of the stepfather, for which the daughter is likely to feel (however inappropriately) very guilty. It also offers a reasonable prospect of involving the father in the treatment necessary to achieve his rehabilitation and to help the family as a whole come to terms with what has happened and work towards less damaging and more satisfactory interrelationships.

1 Gillon R. Philosophical medical ethics. Chichester: John Wiley and Sons, 1986:106-12.

2 Porter $R$, ed. Child sexual abuse within the family. London: Tavistock Publications, 1984:25-32 $52-5,92-106,120$

3 General Medical Council. Professional conduct and discipline: fitness to practice. London: GMC 1987:19-22.

4 British Medical Association. The handbook of medical ethics. London: BMA, 1984:12. 


\section{Clare Dyer comments:}

Doctors, like the public in general, are under no general duty in law to report a crime, though requirements may be imposed in particular cases by statute. The United States, Canada, and some Australian states have made the disclosure of suspected child abuse a statutory obligation, but this is not the case in the United Kingdom. General practitioners could not be found guilty of abetting the offence of sexual intercourse with a girl under 16-the Gillick case has established that a doctor could be regarded as abetting this offence only if he actually intended to facilitate unlawful intercourse-so it seems unlikely that any criminal culpability would arise.

As there is no statutory duty on the doctor any civil action would have to be framed in negligence. I know of no case in law dealing directly with this point, but to succeed the plaintiff would have to show that no reasonably competent general practitioner would have failed to disclose confidential information in these circumstances. The fact that there is an accepted code of practice for the county is relevant, but this would not of itself mean that any general practitioner who failed to follow it would necessarily be held to be negligent. How far the general practitioner could have foreseen what happened would also be relevant. We are told that there were threats of violence, but no actual violence on the stepfather's part is mentioned. Should the threats of violence and the stepfather's (?) drinking have been sufficient to alert her to the danger? It seems doubtful. In the United States a psychotherapist was held negligent for failing to warn a potential homicide victim of the danger, but I know of no such case in the United Kingdom.

The General Medical Council's "blue book" is not a complete code of medical ethics but a guide to the types of professional misconduct that have led or, in the council's opinion, might lead to disciplinary action. Doctors are obliged to protect patients' confidences, but this duty is not absolute and may be overridden in several circumstances. In exceptional cases a doctor may disclose confidential information to a third party other than a relative if it is in the patient's best interests and every reasonable effort has been made to persuade the patient to consent; rarely, disclosure may be justified by the public interest-for example, investigation by the police of a very serious crime. Under these guidelines the general practitioner in this case would certainly be entitled to disclose the information, but the blue book places her under no duty to do so. Any disciplinary proceedings would therefore have to be brought under the general heading of "neglect or disregard of personal responsibilities to patients for their care and treatment." Proceedings are brought only when doctors seem to have seriously disregarded or neglected their professional duties - for example, by failing to visit or provide to arrange treatment when necessary. According to the blue book, a good standard of medical care includes "appropriate and prompt action upon evidence suggesting the existence of a condition requiring urgent medical attention" and "readiness, where the circumstances so warrant, to consult appropriate professional colleagues." I would doubt that this general practitioner, without the benefit of hindsight, fell sufficiently short of the required standard to warrant a charge of serious professional misconduct.

\section{The case of mental handicap registers}

The demand for information from clinical records of patients by the local authority's social services department for its computerised mental handicap register, without written informed consent from the patient if he or she is competent or from the nearest relative in the case of severely mentally handicapped incompetent patients, is a perplexing issue that needs to be aired.

I have been confronted with this issue from time to time in the past two or three years, and it resulted recently in an unpleasant conflict with a senior officer of the social services department, who accused me of protecting my own interests rather than those of my patients. When I asked him to obtain written informed consent and emphasised that this was required by the health authority before any basic information about the patient could be transferred to the mental handicap register I was accused not only of self protection but also of obstruction.

I could not understand this reaction to my simply asking the social services department to comply with the basic rights of patients and their families-that is, to ask them for their consent before personal details are computerised, albeit for as good a cause as planning the welfare of this vulnerable group of patients.

I sincerely hope that the Department of Health and Social Security with the British Medical Association and appropriate bodies will urgently set clear cut guidelines on this issue.

\section{Dr Jeannette Naish comments:}

A comprehensive service to meet the needs of mentally handicapped people can be provided only through the cooperative efforts of the health and local authorities. Sharing and coordinating information are necessary to avoid duplication and facilitate the delivery of services but frequently lead to a conflict of loyalties. The demand for information for a computerised mental handicap register by social services departments faced by Dr Singh illustrates this problem.

Basic information contained in a mental handicap register such as name, address, and age need not be controversial, but histories, particularly social and psychiatric histories, and diagnoses are potentially sensitive as far as the patients and their families are concerned. Access to this information and, more specifically, the use made of this sensitive information are at issue. Disclosure of confidential information without the patient's knowledge and consent destroys the trust that the patient has in the doctor and any other member of the team concerned with care. Social workers are not bound by the same confidential constraints as National Health Service employees, and the concern is that there may not be sufficient safeguards against information being divulged to other, unauthorised, agencies or that information may be used against the best interests of the patient.

The problem is not simply about releasing information to social services departments but also about agreeing constraints on what can be done with the information. This could be overcome by social workers becoming members of the multidisciplinary community mental handicap team and undertaking to abide by the constraints of confidentiality of the team. Otherwise, access to the computerised register would have to be restricted to non-controversial information.

\section{Dr D P Addy comments:}

I think that much depends on the information to be imparted. Much of the information required for a mental handicap register is non-confidential and known to many people. Difficulty may arise with some sensitive information such as disputed or unorthodox paternity or certain diagnoses (congenital syphilis, non-accidental injury). I think the situation is also different in the early stages after mental handicap has been diagnosed in a child, when the parents are still coming to terms with the problem. At that stage strict confidentiality may be more important than later on when the child is attending a special school and relevant information is available to many professionals. Obviously, social services departments have an important job to do and doctors should cooperate with them as much as possible within their own ethical framework.

I think it is legitimate for doctors to decide for themselves what information is routine and non-confidential and can be released to other properly interested professionals without specific consent and what is confidential and needs the formal consent of the patient or responsible relative before it can be divulged. Hospital doctors who frequently receive this kind of request from social services departments could, if they think it necessary, pre-empt the problem by routinely asking for consent when they see a patient and discussing what information the family regard as strictly confidential. In my experience most families appreciate the need for all professionals 
concerned in a case to share basic information and it is rare for them to object.

\section{Dr Raanan Gillon comments:}

Given the constraints of space suffice it for this case simply to say that I would argue that the doctor was right to require evidence of approved proxy consent to include the mentally handicapped patient's name on the social services department's computer register, precisely on the grounds offered by the social worker against giving proxy consent-notably, protection of (and respect for) a specially "vulnerable group of patients."

\section{Clare Dyer comments:}

A doctor's duty of confidentiality requires him or her to keep information acquired as part of the doctor-patient relationship confidential unless the patient consents to disclosure. But, as discussed above, the duty is not absolute. As, exceptionally, a doctor may disclose information to a third party in the patient's best interests even when the patient has been asked to consent but has refused, then surely there can be no objection to such a disclosure when the patient, because of severe mental handicap, is unable to consent. If the patient is an adult a parent or relative cannot consent on his behalf anyway so, legally, there is no point in seeking such consent.

\title{
Portraits from Memory
}

\section{3-Professor Colin Beattie (1902-87)}

\author{
JAMES HOWIE
}

As a microbiologist Colin Beattie earnt an international reputation from his work on toxoplasmosis. He lifted the parasite Toxoplasma gondii from obscurity in medical circles and made it his main interest. It remained so until his death; and his work compelled others to give it a place in their thinking. In all his accounts of this work he invariably gave generous credit to his collaborators, especially his juniors, although without Beattie's own pioneer work it would never have come to their attention. He also did useful work on brucellosis and typhus, and he had an all round interest and outlook that made it worth while discussing with him any current problem or topic of interest.

\section{Microbiology, marriage, and the Middle East}

In 1928 he qualified in medicine from the University of Edinburgh. After house appointments he worked for seven years in the bacteriology department of the university under Professor T J Mackie, a celebrated and, as some would say, a formidable and energetic head of department of whom it was said that he never walked anywhere, he always ran.

In 1937 Beattie was appointed professor of bacteriology in the

\section{Edinburgh EH13 OBU}

Sir JAMES HOWIE, MD, FRCP

Correspondence to: 34 Redford Avenue, Edinburgh EH13 OBU.
Royal Faculty of Medicine of Iraq and director of the government bacteriology laboratory in Baghdad. In the same year he married $\mathrm{Dr}$ May Christison, a Scot with a Canadian arts degree who was working for her $\mathrm{PhD}$ in the Edinburgh University bacteriology department. Always interested in the arts, they made a splendid team and became experts in the mysteries of oriental carpets. Beattie was happy during his nine years in Baghdad and built up an effective service in bacteriology there.

In 1946, howeter, he returned to Britain and in due course was appointed to the chair of bacteriology in Sheffield University. He was also made an honorary consultant to the United Sheffield Hospitals. His department initially consisted of himself and one lecturer. He built it up to a flourishing and respected institution and established an effective collaboration with the Sheffield hospitals. Even after his official retirement in 1967 he continued to act as locum consultant for various hospitals and was still active and useful in this capacity into his late 70 s. So much for Beattie the microbiologist-a good one, much respected.

\section{First class instruction}

Of Beattie as a professor and as a person there is more to be said. He was a very well educated man, having taken an MA in classics before studying medicine. He was interested in anything and everything useful and he read widely. He had time for everyone and everything, and he and May entertained generously and handsomely. He always artanged that his staff met his external examiners in an informal party at his house and thus widened their contacts and areas of interest. He lectured well, never regarding teaching as other than a matter of first class importance. As an examiner of undergraduates he was fair and always aware of the need to put candidates at their ease before getting down to the serious part of their vivas. This is perhaps surprisingly often the intention of examiners, but few knew as well as Beattie did exactly how to make the good intention a reality. If a student obviousily could not answer a question he simply changed the subject, not-as so many dopersisting and driving home the sense of failure. As soon as a 